\title{
HIGH PERFORMANCE LIQUID CHROMATOGRAPHIC METHOD FOR DIRECT DETERMINATION OF DIAZEPAM IN WHOLE BLOOD AND SERUM - OPTIMIZATION OF SOLID-PHASE EXTRACTION METHOD
}

Dragica Zendelovska, Kristina Pavlovska, Emilija Atanasovska, Kalina Gjorgjievska, Marija Petrusevska

Institute of Preclinical and Clinical Pharmacology and Toxicology, Ss. Cyril and Methodius University, Medical Faculty, 50 Divizija bb, 1000 Skopje, Republic of Macedonia

Corresponding author: Marija Petrusevska, e-mail: marija.petrusevska@medf.ukim.edu.mk,Tel.: +389 23111828

\begin{abstract}
Herein, we present a simple and rapid high performance liquid chromatographic (HPLC) method with UV-detection for the direct determination of diazepam in whole blood and serum that can be used for monitoring diazepam levels in clinical samples analysis. The isolation of diazepam and the internal standard bromazepam from serum and whole blood samples was performed using solid phase extraction method with RP select B cartridges. The analytes were separated employing a reversed phase $\mathrm{C} 8$ column with a mobile phase composed of $0.1 \%(\mathrm{~V} / \mathrm{V})$ triethylamine in water $(\mathrm{pH} 3.5)$ and acetonitrile $(63: 37$, $\mathrm{V} / \mathrm{V})$. UV detection was carried out at $240 \mathrm{~nm}$. Linearity was achieved in the range from 10.0-1000.0 $\mathrm{ng} / \mathrm{ml}$ for serum and whole blood. The method was applied to spiked and real biological samples after an oral administration of $10 \mathrm{mg}$ diazepam. In conclusion, the proposed method is simple, rapid and provides efficient clean-up of the complex biological matrix and high recovery of diazepam.
\end{abstract}

Keywords: diazepam, solid-phase extraction, HPLC, whole blood, serum

\section{INTRODUCTION}

Diazepam (7-chloro-1, 3-dihydro-1-methyl-5-phenyl-2H-1, 4-benzodiazepin-2-one) is a benzodiazepine generally used as hypnotic, anxiolytic and muscle relaxant. Benzodiazepines are considered one of the major drug abuse groups and they belong to the most common class of drugs in the clinical toxicology practice. Diazepam is routinely prescribed as the standard first-line treatment for acute convulsions and prolonged status epilepticus [1]. It is a lipophilic drug and can readily pass through the blood-brain barrier (BBB) and some other lipophilic tissues. Howev- er, due to its lipophilicity, it is rapidly redistributed out of the brain. Due to fast distribution, serum levels of diazepam fall down quickly in the brain leading to repeated dosing, accumulation in the body, and serious complications [2]. The half-life of diazepam after oral administration in normal volunteers and psychiatric patients, particularly after prolonged therapy was estimated to be in the range from 9 to $35 \mathrm{~h} \mathrm{[3].}$

Several high-performance liquid chromatographic (HPLC) methods have also been reported for the determination of diazepam alone [4-8] 
or in combination with other drugs [8-12] from pharmaceutical dosage forms, as well as in the forensic medicine in biological samples. Reported extraction include extraction mode with a polydimethylsiloxane $[12,13]$ and solvent-modified solid-phase microextraction by capillary gas chromatography [14].

The aim of this study is to develop a new HPLC method suitable for determination of diazepam in biological fluids employing solid phase extraction for sample preparation, which enables simple and rapid isolation and concentration of the analysed drug. For minimizing the variability caused by sample pre-treatment, we present a method of internal standardization for the quantification of diazepam.

\section{EXPERIMENTAL}

\subsection{Materials}

Diazepam working standard was supplied by Select Chemie, Switzerland and the internal standard bromazepam was obtained from Sigma-Aldrich, Belgium. HPLC grade acetonitrile and methanol were purchased from Across Organics, Belgium. Triethylamine, o phosphoric acid, sodium carbonate and columns for solid phase extraction were obtained from Merck, Germany. ditions

\subsection{Instrument and chromatographic con-}

The development and validation work was carried out on a chromatographic system consisting of Perkin Elmer LC series 200 pump, ultraviolet diode array detector (Perkin Elmer LC 235 C) and autosampler Perkin Elmer LC ISS series 200. The chromatographic system was controlled by the software package Turbochrom Version 4.1. plus and UV-spectrometric data were produced by TurboScan Version 2.0. A reverse phase Supelcosyl LC-8-DB, 250 x $4.6 \mathrm{~mm}$ I.D. (5 $\mu \mathrm{m}$, particle size), protected by a guard column SupelguardTM LC-8-DB $(2 \mathrm{~cm})$ was used for separation. The mobile phase was consisted of $0.1 \%(\mathrm{~V} / \mathrm{V})$ triethylamine in water with $\mathrm{pH}=3.5$ and acetonitrile (63:37, V/V).

In order to achieve a good shape and location of diazepam peaks and the internal standard in the corresponding chromatograms, a series of parameters including composition and
$\mathrm{pH}$ of mobile phase, column packing, flow rate and detection wavelength were tested. The final choice of the stationary phase giving satisfying resolution and run time was LC-8-DB. Triethylamine solution was prepared by adding $100 \mu \mathrm{L}$ triethylamine in $100 \mathrm{~mL} \mathrm{H} 2 \mathrm{O}$ with $\mathrm{pH}$ adjusted to 3.5 with concentrated o-phosphoric acid. The mobile phase was filtered and degassed with helium. Chromatographic separations were performed at $37^{\circ} \mathrm{C}$, with mobile phase flow rate of $1.3 \mathrm{~mL} / \mathrm{min}$ and ultraviolet detection at $240 \mathrm{~nm}$. The injection volume was $100 \mu \mathrm{L}$.

2.3. Solutions, sample preparation and calibration curves

Stock solutions of $1 \mathrm{mg} / \mathrm{mL}$ of diazepam and bromazepam were prepared monthly in methanol and stored at $+4^{\circ} \mathrm{C}$. No change in stability over the period of 1 month was observed. The working solutions were prepared by diluting appropriate portions of these solutions with distilled water.

Human serum was prepared from heparinized whole blood samples. Blood samples were collected from healthy volunteers and stored at $-20^{\circ} \mathrm{C}$. After thawing, samples were spiked daily with stock solutions of diazepam and internal standard.

A solid-phase extraction vacuum manifold (Merck) was used for sample preparation. Spiked sample (total volume $1 \mathrm{~mL}$ ) was introduced into the extraction cartridge with RP select B solid phase $(200 \mathrm{mg})$ under vacuum at 5 psi. The cartridge was conditioned sequentially by $2 \mathrm{~mL}$ methanol, $2 \mathrm{~mL}$ water, followed by $0.1 \mathrm{~mL}$ of $0.1 \mathrm{~mol} / \mathrm{L}$ sodium carbonate solution. For blood samples conditioning of the columns was finished with additional $0.05 \mathrm{~mL}$ of heparin (1000 units $/ \mathrm{mL}$ ). Water $(2 \mathrm{~mL})$ was used to rinse the cartridge. The clean up was accomplished with additional 0.05 $\mathrm{mL}$ of methanol through the cartridge. Elution was then performed in two steps: the first one with 0.2 $\mathrm{mL}$ of methanol and this eluate was collected in a clean tube without vacuum, and the second step with additional $0.1 \mathrm{~mL}$ methanol. The tube with eluate and cartridge were centrifuged at $3500 \mathrm{rpm}$ for $5 \mathrm{~min}$. After centrifugation, the sample was filtered using filter, pore size of $0.45 \mu \mathrm{m}$, and 100 $\mu \mathrm{L}$ volume was injected into the HPLC system.

Seven-point calibration curves were obtained by spiking blank whole blood and serum samples with increasing amounts of diazepam at 20, 50, 100, 250, 500, 750 and $1000 \mathrm{ng} / \mathrm{ml}$ and 
$200 \mathrm{ng} / \mathrm{ml}$ for internal standard. The standard samples were prepared according to the procedure as unknown samples. The calibration curves were obtained by plotting the peak area ratio of diazepam to internal standard versus concentration of diazepam in $\mathrm{ng} / \mathrm{ml}$. The regression equations were calculated by the least-squares method. The robustness of the method was determined by samples analysis under a variety of conditions such as small changes in the percentage of mobile phase acetonitrile, in the $\mathrm{pH}$, in the mobile phase flow rate and in the temperature.

\section{RESULTS AND DISCUSSION}

\subsection{Method development}

A series of studies were conducted in order to develop a convenient and easy-to-use method for quantitative analysis of diazepam in whole

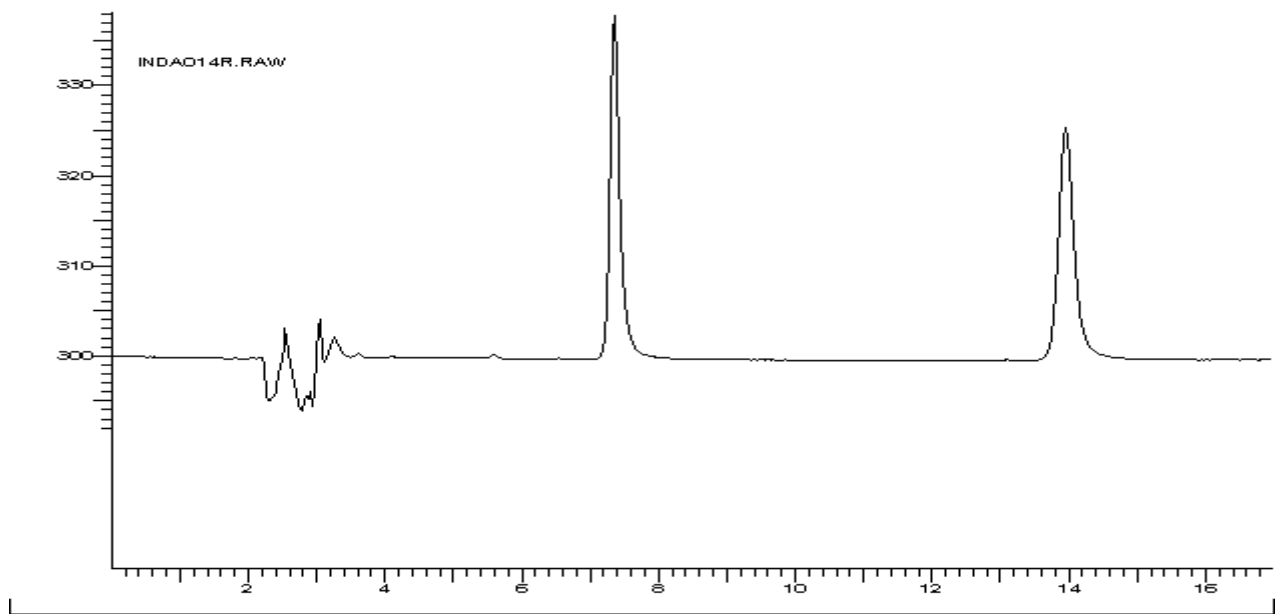

Figure 1. Chromatogram of standard solutions of internal standard (1) and diazepam (2)

blood and serum samples. Several HPLC method variables with respect to their effect on the separation of diazepam and the internal standard (bromazepam) from the matrix were investigated. In addition, the internal standard method can be beneficial when transfers, evaporations and solid phase extraction, or other experimental operations that can cause losses are used since the ration of analyte to internal standard remains constant.

In our extensive preliminary experiments, a series of aqueous mobile phases containing buffer solutions with different $\mathrm{pH}$ values in combination with different modifiers including acetonitrile, 2-propanol and triethylamine with different volume fractions were tested. The results were most satisfactory when mobile phase consisted of $0.1 \%(\mathrm{~V} / \mathrm{V})$ triethylamine in water with $\mathrm{pH}$ 3.5 and acetonitrile in volume fractions 63:37. A set of column packing including $\mathrm{C} 8, \mathrm{C} 18$ and LC-8-DB with different lengths and particle sizes were tested and the LC-8-DB packing showed the best separation. Among several flow-rates tested $(0.8-2 \mathrm{~mL} / \mathrm{min})$ the rate of $1.3 \mathrm{~mL} / \mathrm{min}$ was the best with respect to the location and resolution of the diazepam peaks and internal standard from the interfering peaks. The elution was monitored in the whole UV region and the wavelength of $240 \mathrm{~nm}$ exhibited the best detection.

A typical chromatogram of standard solutions of diazepam and internal standard $(1000 \mathrm{ng} /$ ml) produced by the developed HPLC method is shown in Figure 1. Retention time of internal standard and diazepam are $7.3 \mathrm{~min}$ and $13.9 \mathrm{~min}$, respectively.

In order to obtain satisfactory values for recovery of investigated drugs, different types of solid phase extraction cartridges $(\mathrm{C} 18, \mathrm{TSC}$ and RP-select B) were tested.

The extraction recoveries were calculated by comparing the peak height of diazepam obtained for low, medium and high level quality control samples $(n=3$, for each level for diazepam; $\mathrm{n}=9$, for internal standard) and those resulting from the direct injection ( $\mathrm{n}=3$, working solutions) of the theoretical amount of either diazepam or internal standard ( $=100 \%$ recovery). These results are presented in Table 1.

As can be seen, the satisfactory values for recovery of diazepam and internal standard were obtained when solid phase extraction was performed on RP-select B cartridges. These cartridg- 
Table 1. Absolute recoveries of diazepam and internal standard from spiked serum and blood samples

\begin{tabular}{cccc}
\hline & \multicolumn{3}{c}{ Mean recovery (\%) } \\
\cline { 2 - 4 }$\gamma($ diazepam) $/(\mathrm{ng} / \mathrm{mL})$ & $\begin{array}{c}\text { TSC } \\
\text { serum }\end{array}$ & C18 & RP select B \\
25.0 & & & \\
300.0 & 26.4 & 80.3 & 99.7 \\
800.0 & 27.3 & 81.1 & 98.1 \\
$\gamma($ internal & 25.6 & 84.2 & 100.1 \\
standard $) /(\mathrm{ng} / \mathrm{mL})$ & & & \\
200.0 & 22.7 & 82.1 & 99.8 \\
\hline & whole blood & & \\
$\gamma($ diazepam $) /(\mathrm{ng} / \mathrm{mL})$ & & 59.2 & 80.3 \\
25.0 & 34.1 & 52.4 & 80.1 \\
300.0 & 36.8 & 51.3 & 82.7 \\
800.0 & 35.4 & & \\
$\gamma($ internal standard $) /$ & & 52.7 & 79.5 \\
$(\mathrm{ng} / \mathrm{mL})$ & & &
\end{tabular}

es are thus more suitable for enrichment of the somewhat stronger polar compounds, whereas C18 cartridges are more suitable for nonpolar molecules using the same matrix.

Before introducing the spiked samples, cartridges for solid phase extraction were conditioned with $0.1 \mathrm{~mol} / \mathrm{L}$ sodium carbonate solution. In our studies, the buffer for precondition of columns a $\mathrm{pH} 10$ was found to be most appropriate for diazepam and internal standard adsorption. During the initial development of the procedure, a total of $0.5 \mathrm{~mL}$ of methanol was used to elute diazepam in two $0.25 \mathrm{~mL}$ aliquots. Lower eluent volume was advantageous to avoid the need for evaporation at low serum and blood drug levels. It was found that the first $0.2 \mathrm{~mL}$ eluent removed 60 to $65 \%$ of diazepam from the column, and the additional $0.1 \mathrm{~mL}$ of methanol was sufficient to achieve good recovery. The minimum volume required to achieve recovery higher than $80 \%$ was $0.3 \mathrm{~mL}$. When elution of diazepam is carried out in onestep with $0.3 \mathrm{~mL}$ methanol, unsatisfactory values for recovery were obtained. The investigations show that the best results for recovery of diazepam were obtained with the addition of $0.2 \mathrm{~mL}$ of methanol followed by another portio $\mathrm{n}$ of $0.1 \mathrm{~mL}$.

Under the chromatographic conditions described, diazepam and the internal standard peaks were well resolved and endogenous serum and blood components did not give any interfering peaks. Typical chromatograms of blank serum and blood in comparison to spiked samples are shown in Figure 2.

The developed HPLC method was used for analysis of patient plasma samples after oral administration of diazepam.

\subsection{Method validation}

3.2.1. Linearity, limit of detection and quantification

Linear detector response for the peak-height ratios of diazepam to internal standard was observed in concentration range between 20.0 and $1000.0 \mathrm{ng} / \mathrm{mL}$ with correlation coefficients of 0.9983 and 0.9978 for serum and blood samples, respectively. Respective regression equations for diazepam obtained after preparation of samples using solid-phase extraction were, $y=0.0153 \cdot \gamma$ +0.024 for serum and $\mathrm{y}=0.0149 \bullet \gamma+0.015$ for blood samples.

Under the experimental conditions used, the lower limit of detection was $10 \mathrm{ng} / \mathrm{ml}$ at a signalto-noise ratio of 3 . The limit of quantification was defined as the lowest amount detectable with a precision of less than $15 \%(n=5)$ and an accuracy of $\pm 15 \%(n=5)$. The limits of quantification were $20 \mathrm{ng} / \mathrm{ml}$ for serum and blood samples. 


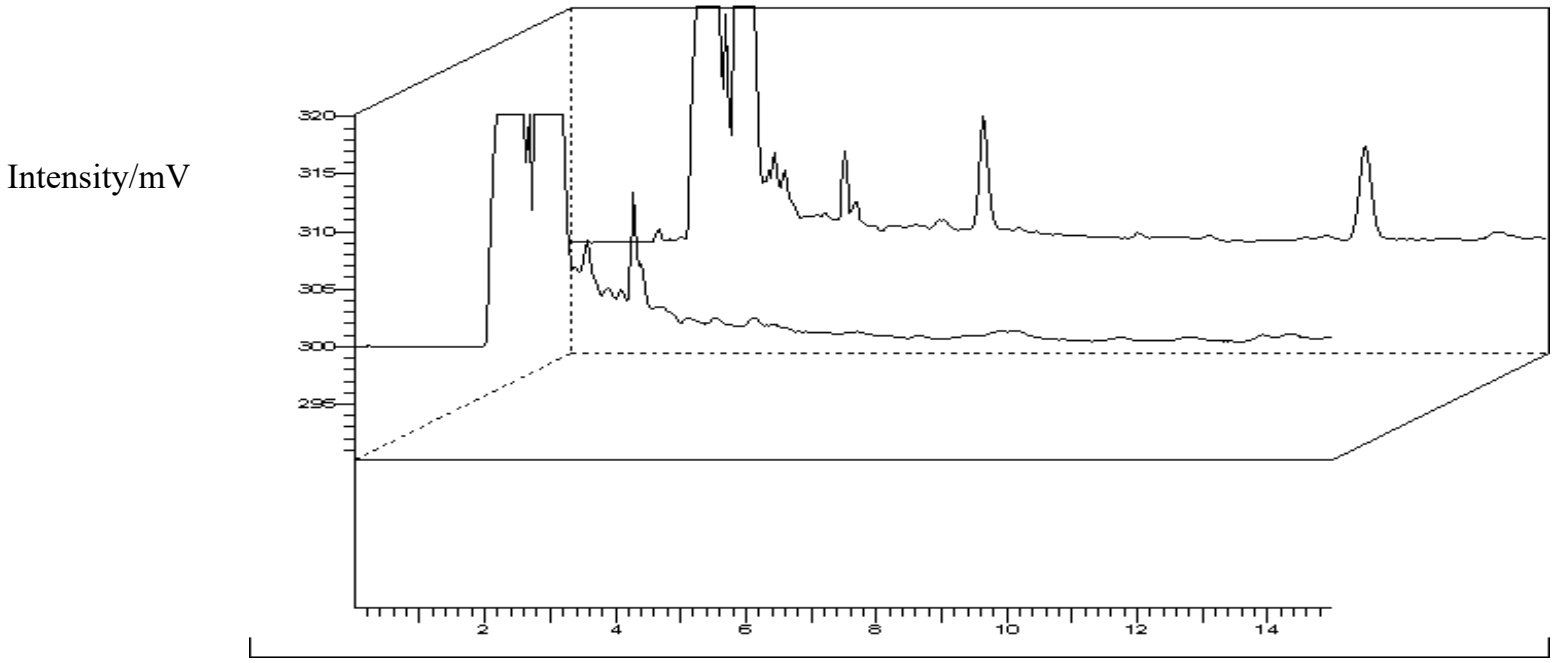

(a)

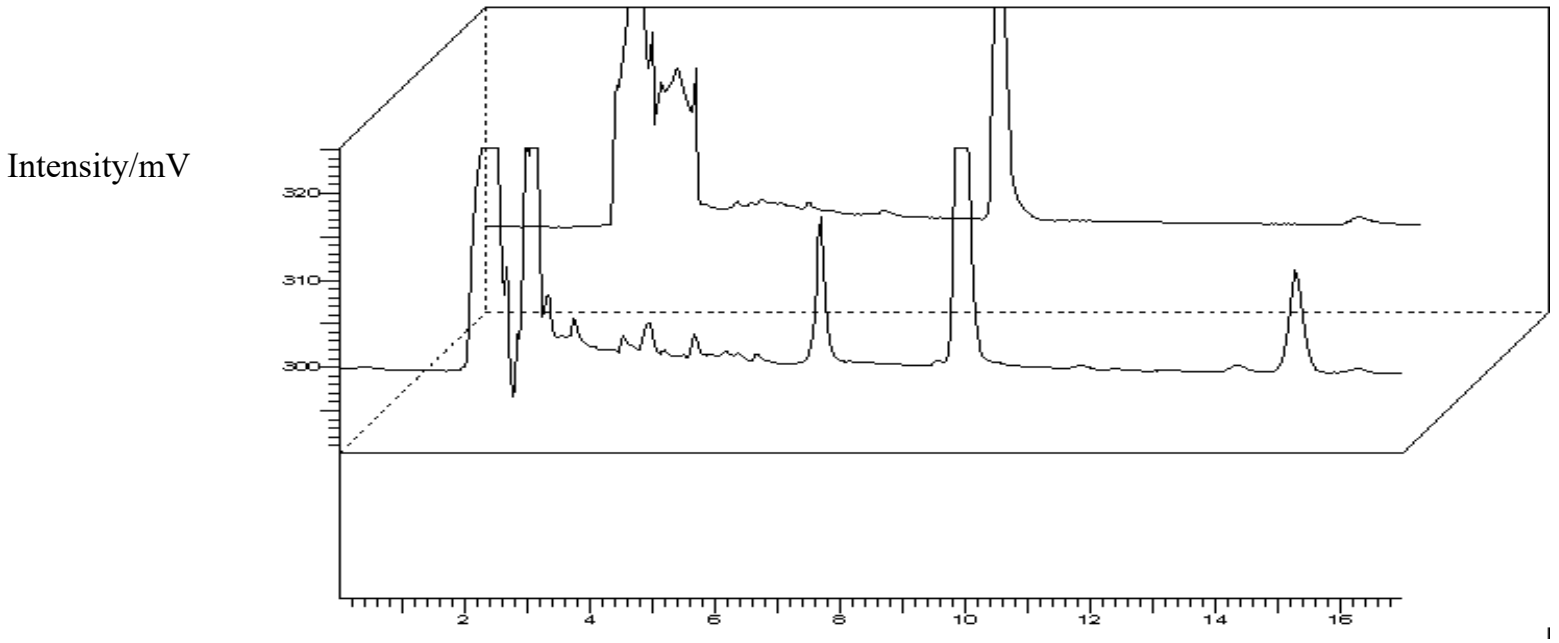

(b)

Figure 2. Chromatograms of blank (1) and spiked (2) serum (a) and blood (b) samples.

\subsubsection{Precision and accuracy}

In one day and on three different days, spiked samples from each concentration used for construction of calibration curves were prepared in triplicate and analyzed by the proposed HPLC method. Then, the corresponding coefficients of variation were calculated. The intra- and inter-day variations of the method throughout the linear range of concentrations are shown in Table 2. The RSD for intra-day precision ranged from 2.8 to $6.2 \%$ for serum samples and from 4.7 to $7.1 \%$ for blood samples. For inter-day precision, RSDs ranged from 3.0 to $6.1 \%$ for serum samples and from 3.3 to $7.9 \%$ for blood samples. These data indicate a considerable degree of precision and reproducibility for the method both during one analytical run and between different runs.
Intra- and inter-day accuracy was determined by measuring blood and serum quality control samples at low, middle and high concentration levels. An indication of accuracy was based on the calculation of the relative error of the mean observed concentration as compared to the nominal concentration. Accuracy data are presented in Table 2. Relative errors at all three concentrations studied for serum and blood samples are less than $4.4 \%$ and it is obvious that the method is remarkably accurate which ensures obtaining of reliable results.

3.2.3. Stability of diazepam in serum and blood samples

Stability of diazepam in serum and blood was investigated using spiked samples at two dif- 
Table 2. Intra-and inter-day precision and accuracy data

\begin{tabular}{|c|c|c|c|c|}
\hline \multirow{2}{*}{$\begin{array}{c}\text { Diazepam } \\
\text { nominal } \\
\text { concentration } \\
(\mathrm{ng} / \mathrm{mL})\end{array}$} & \multicolumn{2}{|l|}{ Intra-day } & \multicolumn{2}{|c|}{ Inter-day } \\
\hline & $\begin{array}{l}\text { Mean }(\mathrm{n}=3) \text { observed } \\
\text { concentration }(\mathrm{ng} / \mathrm{mL})\end{array}$ & $\begin{array}{c}\text { Relative } \\
\text { standard } \\
\text { deviation }(\%)\end{array}$ & $\begin{array}{l}\text { Mean }(\mathrm{n}=9) \text { observed } \\
\text { concentration }(\mathrm{ng} / \mathrm{mL})\end{array}$ & $\begin{array}{c}\text { Relative } \\
\text { standard } \\
\text { deviation (\%) }\end{array}$ \\
\hline \multicolumn{5}{|l|}{ Precision } \\
\hline \multicolumn{5}{|l|}{ Serum } \\
\hline 20.0 & 19.8 & 6.2 & 19.3 & 6.1 \\
\hline 50.0 & 49.2 & 5.4 & 50.1 & 4.6 \\
\hline 100.0 & 100.3 & 2.8 & 101.4 & 3.9 \\
\hline 250.0 & 249.1 & 3.4 & 249.3 & 3.0 \\
\hline 500.0 & 498.4 & 4.2 & 498.9 & 3.2 \\
\hline 750.0 & 750.2 & 4.0 & 748.2 & 3.1 \\
\hline 1000.0 & 997.5 & 4.1 & 998.5 & 3.4 \\
\hline \multicolumn{5}{|l|}{ Whole blood } \\
\hline 20.0 & 19.4 & 7.1 & 19.5 & 7.9 \\
\hline 50.0 & 50.2 & 6.8 & 50.4 & 7.2 \\
\hline 100.0 & 99.6 & 6.4 & 101.2 & 6.9 \\
\hline 250.0 & 248.6 & 6.0 & 248.7 & 5.6 \\
\hline 500.0 & 495.9 & 5.7 & 496.3 & 4.9 \\
\hline 750.0 & 748.5 & 5.5 & 747.2 & 4.6 \\
\hline 1000.0 & 998.1 & 4.7 & 998.5 & 3.3 \\
\hline Accuracy & & $\begin{array}{l}\text { Rel ative error } \\
(\%)\end{array}$ & & $\begin{array}{c}\text { Rel ative error } \\
(\%)\end{array}$ \\
\hline \multicolumn{5}{|l|}{ Serum } \\
\hline 25.0 & 25.2 & -0.8 & 25.3 & -1.2 \\
\hline 300.0 & 298.4 & 0.5 & 297.6 & 0.8 \\
\hline 800.0 & 798.3 & 0.2 & 797.4 & 0.3 \\
\hline \multicolumn{5}{|l|}{ Whole blood } \\
\hline 25.0 & 24.6 & 1.6 & 26.1 & -4.4 \\
\hline 300.0 & 297.5 & 0.8 & 298.7 & 0.4 \\
\hline 800.0 & 797.4 & 0.3 & 797.4 & 0.3 \\
\hline
\end{tabular}

ferent concentration levels i.e., $20 \mathrm{ng} / \mathrm{mL}$ and 1000 $\mathrm{ng} / \mathrm{mL}$ and were prepared in duplicate. Spiked samples were analysed after different storage conditions: immediately, after staying in an autosampler for 2, 12 and 24 hours, after one and three freeze/thaw cycles and after 1 month stored at -20 ${ }^{\circ} \mathrm{C}$. The results from the stability studies show that relative errors at two different concentrations studied were in range from 0.5 to $7.3 \%$ and it is obvious that diazepam added to plasma are stable in the different storage conditions.

\subsubsection{Robustness of the method}

To assess the robustness of the quantitative method, deliberate changes in flow rate, percentage of acetonitrile, $\mathrm{pH}$ and temperatures were performed. These alterations did not show any significant changes on retention time and peak parameters for both diazepam and the internal standard. According to the system suitability pa- rameters under the modified conditions and the specificity of the method, we can conclude that the method conditions are robust.

\section{CONCLUSION}

The developed HPLC method employing solid-phase extraction for sample preparation is simple, convenient and economical for the determination of diazepam in serum and blood samples. This method provides a linear response across a wide range of concentrations and it utilizes a mobile phase which can be easily prepared and diluent is economic, readily available. The validation data demonstrate good precision and accuracy, which proves the reliability of the proposed method. Diazepam and the internal standard bromazepam have been successfully separated. 
The proposed method is simple, rapid and provides efficient clean-up of the complex biological matrix and high recovery of diazepam. Finally, the method has been implemented to monitor diazepam levels in clinical samples.

\section{REFERENCES}

1. Shorvon S, Perucca E, Engel J., Jr . The treatment of epilepsy. 3. UK: Wiley-Blackwell West Sussex; 2009.

2. Sruthi A, Tejaswi P, Thanuja N, Sudheer Kumar D, Vivek Sagar V. Simple RP-HPLC method for estimation of diazepam in tablet dosage form. $\mathrm{J}$ Pharm Res 2013; 6(1):140-144

3. Eatman FB, Colburn WA, Boxenbaum HG, Posmanter HN, Weinfeld RE, Ronfeld R, Weissman L, Moore JD, Gibaldi M, Kaplan SA. Pharmacokinetics of diazepam following multiple-dose oral administration to healthy human subjects. J Pharmacokinet Biopharm. 1977; (5):481-94.

4. Rouini MR, Ardakani YH. An improved HPLC method for rapid quantitation of diazepam and its major metabolites in human plasma. Talanta 2008; 75: 671-676.

5. Moghaddam KA, SolataniUddin MNF, Samanidou VF, Papadoyannis IN. Development and validation of an HPLC method for the determination of benzodiazepines and tricyclic antidepressants in biological fluids after sequential SPE. J Sep Sci 2008, 31(13): 2358-70.

6. Samanidou VF, Nika MK, Papadoyannis IN. Development of an HPLC method for the monitoring of tricyclic antidepressants in biofluids. J Sep Sci 2007; 30(15): 2391-400.

7. Surya Prakash G, Neeraj U, Gopal G. Development and validation of spectrophotometric, HPTLC and
HPLC methods for the determination of Imipramine and Chlordiazepoxide in pharmaceutical dosage forms. Der Pharmacia Sinica 2012; 3(2): 185-192.

8. Patel S. Development and Validation of HPTLC Method for Simultaneous Determination of Diazepam and Propranolol Hydrochloride in Tablet Dosage Form. Int J Pharma Front Res 2011; 1(3): 29-37

9. Lavinia G. Hinescu, Cristina M. Ranetti, Mihaela I, Elena I, Constantin D, Constantin M, Cristiana C, Victor AV. HPLC method for the simultaneous determination of the components of an aqueous antidote solution. Farmacia 2011; 59(1): 97-105.

10. Tania VM, Maria JR, Quezia BC, Maria ET. Development and Optimization of a HPLC-DAD Method for the Determination of Diverse Pharmaceuticals in Estuarine Surface Waters. J Chromato Sci 2010; 48: 176-182.

11. Tulja Rani G, Gowri shankar D, Kadgapathi P, Satyanarayana B. Development of an RP-HPLC Method for the Simultaneous Estimation of Propranolol Hydrochloride and Diazepam in Combined Dosage form. Ind J Pharm Edu Res 2011; 45(4): 296-300.

12. Mohammad NU, Victoria FS, Ioannis NP. Simultaneous determination of 1,4-benzodiazepines and tricyclic antidepressants in saliva after sequential SPE elution by the same HPLC conditions. J Chinese Chem Soc 2011; 58: 142-154

13. Oliveira MH, Queiroz MEC, Carvalho D, Silva SM, Lanca FM. Determination of Diazepam in Human Plasma by Solid-Phase Microextraction and Capillary Gas Chromatography-Mass Spectrometry. Chromatographia 2005; 62 (3-4): 215 219

14. Krogh M, Grefslie H, Rasmussen KE. Solvent-modified solid-phase microextraction for the determination of diazepam in human plasma samples by capillary gas chromatography. J Chroma B 1997; 689(2):357-364 


\section{Резиме}

ВИСОКО-ЕФИКАСНА ТЕЧНА ХРОМАТОГРАФСКА МЕТОДА

ЗА ДИРЕКТНО ОДРЕДУВАЊЕ НА ДИЈАЗЕПАМ ВО ПОЛНА КРВ

И СЕРУМ-ОПТИМИЗАЦИЈА НА ЦВРСТОФАЗЕН ЕКСТРАКЦИСКИ МЕТОД

\section{Драгица Зенделовска, Кристина Павловска, Емилија Атанасовска, Калина Ѓорѓ́евска, Марија Петрушевска}

Институт за претклиничка и клиничка фармакологија со токсикологија, Универзитет „Св. Кирил и Методиј“, Медицински факултет, 50 дивизија бб, 1000 Скопје, Република Македонија

Целта на оваа студија беше да се развие едноставен и брз хроматографски метод преку УВ-детекција за директно одредување на дијазепам во полна крв и серум за следење на неговите концентрации во клиничката средина. Изолацијата на дијазепам и на интерниот стандард бромазепам од серум и полна крв беше изведено преку метод на екстракција преку цврста фаза и користење на $\mathrm{RP}$ селект B кертриџи. Аналитите беа издвоени преку користење на реверзнофазна C8 колона со мобилна фаза составена од $0,1 \%(\mathrm{~V} / \mathrm{V})$ триетиламин во вода (рH 3.5) и ацетонитрил $(63: 37, \mathrm{~V} / \mathrm{V})$, а УВ-детекцијата беше изведена на $240 \mathrm{~nm}$. Линеарноста на методот беше достигната во концетрациски ранг од 10 до $1000 \mathrm{ng} / \mathrm{ml}$ за серум и полна крв. Апликацијата на развиениот метод беше изведена на спајкувани и вистински биолошки примероци по перорална администрација на $10 \mathrm{mg}$ дијазепам. Предложениот метод обезбедува едноставно, брзо и ефикасно чистење на комплексниот биолошки матрикс со висок степен на добивка на дијазепам.

Клучни зборови: дијазепам, екстракција преку цврста фаза, полна крв, серум 